\title{
A magyarországi emlő- és méhnyakszürés retrospektív vizsgálatának jellemzői a halálozási és megbetegedési adatok tükrében
}

\author{
Sárváry Attila dr. ${ }^{1}$ - Bálint Pál Csaba ${ }^{2}$ - Gyulai Anikó ${ }^{3}$ - Kósa Zsigmond dr. ${ }^{3}$ \\ ${ }^{1}$ Debreceni Egyetem, Egészségügyi Kar, Ápolástudományi Tanszék, Nyíregyháza \\ ${ }^{2}$ Szent Margit Kórház, Kardiológiai Osztály és Kardiológiai Rehabilitációs Osztály, Budapest \\ ${ }^{3}$ Debreceni Egyetem, Egészségügyi Kar, Védőnői Módszertani és Népegészségtani Tanszék, Nyíregyháza
}

Bevezetés: A szervezett emlő- és méhnyakszűrés bevezetésére a népegészségügyi program keretében került sor Magyarországon. A program azt a célt tüzte ki, hogy 10 év alatt adott korcsoportban az emlórák miatti halálozás 30\%-kal, a méhnyakrák miatti halálozás 60\%-kal csökkenjen 2012-ig.

Célkitüzés: Kutatásunk célja az emlő- és méhnyakrák-mortalitási és -morbiditási adatok retrospektív elemzése, a bevezetett szürővizsgálatok eredményességének vizsgálata volt.

Módszer: Leíró statisztikai elemzést készítettünk a standardizált halálozási és megbetegedési adatokból 1980 és 2015 között, különös tekintettel a 2002-2012-es időszakra.

Eredmények: A 45-64 éves nók emlőrák miatti halálozása 28,3\%-kal, az emlőrák incidenciája 23,6\%-kal csökkent, míg az in situ carcinoma incidenciája 242\%-kal emelkedett 2002 és 2012 között. A 25-64 éves nők méhnyakrák miatti halálozása 25,5\%-kal, a méhnyakrák incidenciája 21,2\%-kal csökkent, míg az in situ carcinoma incidenciája 13,3\%-kal növekedett a 2002-2012-es időszakban.

Következtetés: Bár mind az emlőrák, mind a méhnyakrák miatti halálozás jelentősen csökkent Magyarországon, a halálozás csökkenése a méhnyakrák esetén jelentősen elmaradt a várt célértéktől.

Orv Hetil. 2019; 160(49): 1948-1956.

Kulcsszavak: emlőrák, méhnyakrák, szűrés, halálozás, megbetegedés

\section{Retrospective examination of the Hungarian breast and cervical cancer screening programmes according to mortality and morbidity data}

Introduction: The organized breast and cervical screening programs were implemented in the framework of public health program in Hungary in order to reduce breast cancer mortality by $30 \%$ and cervical cancer mortality by $60 \%$ in given age groups within 10 years by 2012 .

Aim: The aim of our study was to conduct a retrospective analysis of mortality and morbidity data and to evaluate the effectiveness of the implemented screening programs.

Method: Descriptive statistical analysis was performed by age-standardized mortality and morbidity data between 1980 and 2015 with special regard to the period of 2002-2012.

Results: Breast cancer mortality of women aged $45-64$ reduced by $28.3 \%$, the incidence reduced by $23.6 \%$ and the incidence of in situ carcinoma increased by $242 \%$ between 2002 and 2012 . Cervical cancer mortality of women aged $25-64$ years reduced by $25.5 \%$, the incidence reduced by $21.2 \%$, and the incidence of in situ carcinoma increased by $13.3 \%$ during 2002-2012.

Conclusion: Although both breast cancer and cervical cancer mortality substantially decreased in Hungary, the decrease in cervical cancer did not reach the target value.

Keywords: breast cancer, cervical cancer, screening, mortality, morbidity

Sárváry A, Bálint PCs, Gyulai A, Kósa Zs. [Retrospective examination of the Hungarian breast and cervical cancer screening programmes according to mortality and morbidity data]. Orv Hetil. 2019; 160(49): 1948-1956.

(Beérkezett: 2019. április 29.; elfogadva: 2019. július 2.) 


\section{Rövidítések}

C50 = emlőrák; C53 = méhnyakrák; D05 = az emlő in situ carcinomája; D06 = a méhnyak in situ carcinomája; EU13 = a 2004-ben és utána csatlakozott európai uniós tagállamok; EU15 = az Európai Uniót 2004 előtt alkotó tagállamok; EU28 = az Európai Unió 28 tagállama; HPV = humán papillomavírus; $\mathrm{WHO}=$ (World Health Organization $)$ Egészségügyi Világszervezet

Magyarországon a daganatos betegségek miatti halálozás a vezetó halálokok közé tartozik, 2016-ban a $0-\mathrm{X}$ éves korcsoportban a második, a 0-64 éves korcsoportban az első helyen szerepelt mindkét nemben $[1,2]$. A nők körében a leggyakoribb daganatos megbetegedés az emlörák, a méhnyakrák a 5 . helyen szerepelt, míg a daganatos halálozás tekintetében az emlőrák a második, a méhnyakrák az 5. helyen állt Magyarországon $[2,3]$. A 25-64 éves magyar nők daganatos betegségek miatti halálozása 2011-ben közel kétszer, az emlőrák okozta halálozása 1,2-szer, a méhnyakrák okozta halálozása 3,1szer volt magasabb az EU15-országokéhoz képest [3].

A daganatos betegségek okozta halálozás csökkentésének egyik hatékony módszere a szervezett szürővizsgálatok alkalmazása. A szervezett szúrés alkalmazását a WHO három daganattípus megelőzésére ajánlja: emlőrák, méhnyakrák és vastag- és végbélrák [4]. Az európai országokban már az 1970-es évek végén megkezdődött az emlö- és a méhnyakszúrés bevezetése [5]. Bár alkalmi jelleggel különböző színtereken és programok keretében már az 1950-es évektől sor került emlő- és méhnyakszûrésre Magyarországon is [6-10], a nemzetközi ajánlásokat figyelembe véve az „Egészséges nemzetért népegészségügyi program, 2001-2010”, majd ennek utódja, „Az egészség évtizedének nemzeti programja" népegészségügyi program tüzte ki célul a szervezett emlő-, méhnyak- és vastag- és végbélszúrés bevezetését $[11,12]$. Országos kiterjesztéssel az emlőszűrés 2002 januárjában a 45-64 éves nők körében, a méhnyakszűrés a 25-64 éves nók körében 2003-ban indult el [13, 14].

A népegészségügyi program a következő konkrét célokat fogalmazta meg az emlö- és méhnyakszúrésre vonatkozóan: a 45-65 éves nói korcsoportban 2012-ig $30 \%$-kal csökkenjen az emlőrák okozta halálozás, a 2565 éves korcsoportban 60\%-kal csökkenjen a méhnyakrák miatti halálozás.

A szervezett népegészségügyi szűrési programokon való részvételi arányokat és a teljes lefedettség alakulását a két daganatféleség esetén korábban részletesen elemezték. Az emlőszưrés esetén az első 2002-2003-as szürési ciklusban a részvételi arány 45,1\%, a 2004-2005-ös ciklusban 37,2\%, míg a következő két szúrési ciklusban 41\% és $42,7 \%$ volt, ami elmaradt a WHO 70\%-os célkitűzésétől [15-18]. A 45-65 éves női célpopulációban a szürési (átszûrtség) és diagnosztikus (átvizsgáltság) emlőfelvétellel rendelkezők aránya (teljes lefedettség) az első szürési ciklusban 53,5\%-os, míg a következő ciklusokban
$50,8 \%, 49,7 \%$ és $51,0 \%$ volt, tehát a $2002-2009$-es időszakban érdemi változás nem történt [15-18].

A szervezett méhnyakszürés első ciklusának (20032005) eredményei szerint a 25-64 éves nói célpopuláció 3 éves lefedettsége $52,6 \%$ volt [19].

$\mathrm{Az}$ emlő- és méhnyakszűrés bevezetésének hatását ezen daganatféleségek okozta halálozásra több tanulmány is vizsgálta $[20,21]$. Ezek alapján az emlőszúrés alkalmazása kb. 30\%-os mortalitáscsökkenést eredményezett a kontrollcsoporthoz képest az 50 év feletti nők körében $[20,21]$. Ugyanakkor a Cochrane Adatbázisban a mammográfiás emlőszürésről 2013-ban megjelent áttekintő elemzés és egy 2018-ban megjelent tanulmány szerint a korábbi vizsgálatok a szürés mortalitáscsökkentő hatását túlbecsülték, annak hatása jóval kisebb mértékû $[22,23]$. A méhnyakszưrés bevezetése után átlagosan 40\%-os halálozáscsökkenést tapasztaltak, ami széles határok között mozgott (11-84\%) [24].

Eddig nem került sor az emlő- és méhnyakrák miatti megbetegedési és halálozási adatok részletes elemzésére Magyarországon. Ezért vizsgálatunk célja az emlő- és méhnyakrák mortalitási és morbiditási adatainak retrospektív elemzése volt, amellyel mérhető a népegészségügyi szűrővvizsgálatok eredményessége, a népegészségügyi programban megfogalmazott célkitûzések elérése.

\section{Adatgyújités}

Az elemzésben használt, a 25-64 éves korcsoportra vonatkozó emlő- és méhnyakrák-halálozási adatok a WHO Európai Régió honlapján elérhetó European Health Information Gateway 2018-as adatbázisából származtak [25]. A korai (25-64 éves korcsoport) halálozási adatokat az 1980 és 2015 közötti időszakra vonatkozóan elemeztük. A magyar nók 45-64 éves korcsoportjára vonatkozó emlőrák-halálozási adatok és a nói lakosság évközepi száma 5 éves korcsoportos bontásban a Központi Statisztikai Hivatal Demográfiai Évkönyveiből (19812016) származtak.

A megbetegedési adatokat az Országos Onkológiai Intézet által múködtetett Nemzeti Rákregiszterből vettük [26]. Az elemzésben az emlőrák (C50), a méhnyakrák (C53), illetve az emlő in situ carcinomája (D05) és a méhnyak in situ carcinomája (D06) megbetegedési adatokat dolgoztuk fel 2001 és 2013 között. Az elemzésből kizártuk a 2000-es év adatait, mert ebben az évben indult az adatgyújtés, ami a sok jelentési hiba miatt az adatok torzításához vezethetett.

\section{Módszer}

A European Health Information Gateway adatbázisban szereplő, a 25-64 éves korcsoportra vonatkozó halálozási adatok standardizáltak, a standard az európai standard populáció kormegoszlása volt. A magyar halálozási adatokat az Európai Uniót 2004 előtt alkotó 15 tagországának (EU15), valamint a 2004-ben és utána csatlakozott 
középkelet-európai országok (EU13) és az Európai Unió összes tagállamának (EU28) halálozási átlagával hasonlítottuk össze. A 45-64 éves magyar nők emlőrákhalálozásának kiszámításához a nyers halálozási arányszámokat az európai standard populáció kormegoszlásával standardizáltuk.

A megbetegedési adatok elemzéséhez az abszolút számokból a Központi Statisztikai Hivatal Demográfiai Évkönyveiből (1981-2014) származó női korcsoportos létszámadatok és az európai standard populáció korcsoportos megoszlásának felhasználásával standardizált incidencia-arányszámokat számoltunk.

\section{Statisztikai analízis}

A 45-64 éves korcsoport emlörák-, valamint a 25-64 éves korcsoport méhnyakrák-incidenciájának, in situ carcinomájának és halálozásának adataira lineáris regressziós modelleket illesztettünk.

\section{Eredmények}

\section{Az emló-és méhnyakrák okozta halálozás alakulása}

Magyarországon az emlőrák miatti korai halálozás - az EU13-országokhoz hasonlóan - 1980-tól 1994-ig emelkedő tendenciát mutatott, majd lassú csökkenés kezdődött (1. ábra). Az EU15-országokban is jellemző volt az
1. táblázat | A 25-64 éves nők emlőrák miatti halálozásának csökkenése Magyarországon és az EU-országcsoportokban, 2002-2012

\begin{tabular}{lccc}
\hline Magyarország & EU28-átlag & EU15-átlag & EU13-átlag \\
$21,6 \%$ & $20,2 \%$ & $21,2 \%$ & $16,5 \%$ \\
\hline
\end{tabular}

Forrás: WHO European Health Information Gateway, 2018

$\mathrm{EU}=$ Európai Unió

1980-as évek elején az emlőrák miatti halálozás növekedése, de a csökkenés hamarabb indult el, és nagyobb mértékű volt, mint hazánkban. Magyarországon a vizsgált időszak elején az emlőrák miatti halálozás megegyezett az EU15-országok átlagával, az 1990-es évek elejétól kezdve meghaladta azt. Az EU13-országok halálozásánál végig magasabb volt a magyar halálozás szintje, ami részben annak tulajdonítható, hogy a kevésbé fejlett országokban általában magasabb az emlőrák miatti mortalitás. A magyar halálozás 2015-ben 1,3-szerese volt az EU15-országok átlagának.

A magyar népegészségügyi program a 2002-2012-es időszakra vonatkozóan határozott meg célokat, ezért ebben az időszakban vizsgáltuk az emlőrák miatti halálozás változását Magyarországon és az EU-országcsoportokban (1. táblázat). Bár az adatok az adatbázisban a szüréssel érintett 45-64 éves korcsoportra nem, csak a 25-64 éves korcsoportra érhetők el, mivel az emlőrák gyakorisága az életkor növekedésével növekszik, ez jó összehasonlítási lehetőséget biztosít számunkra. A 25-

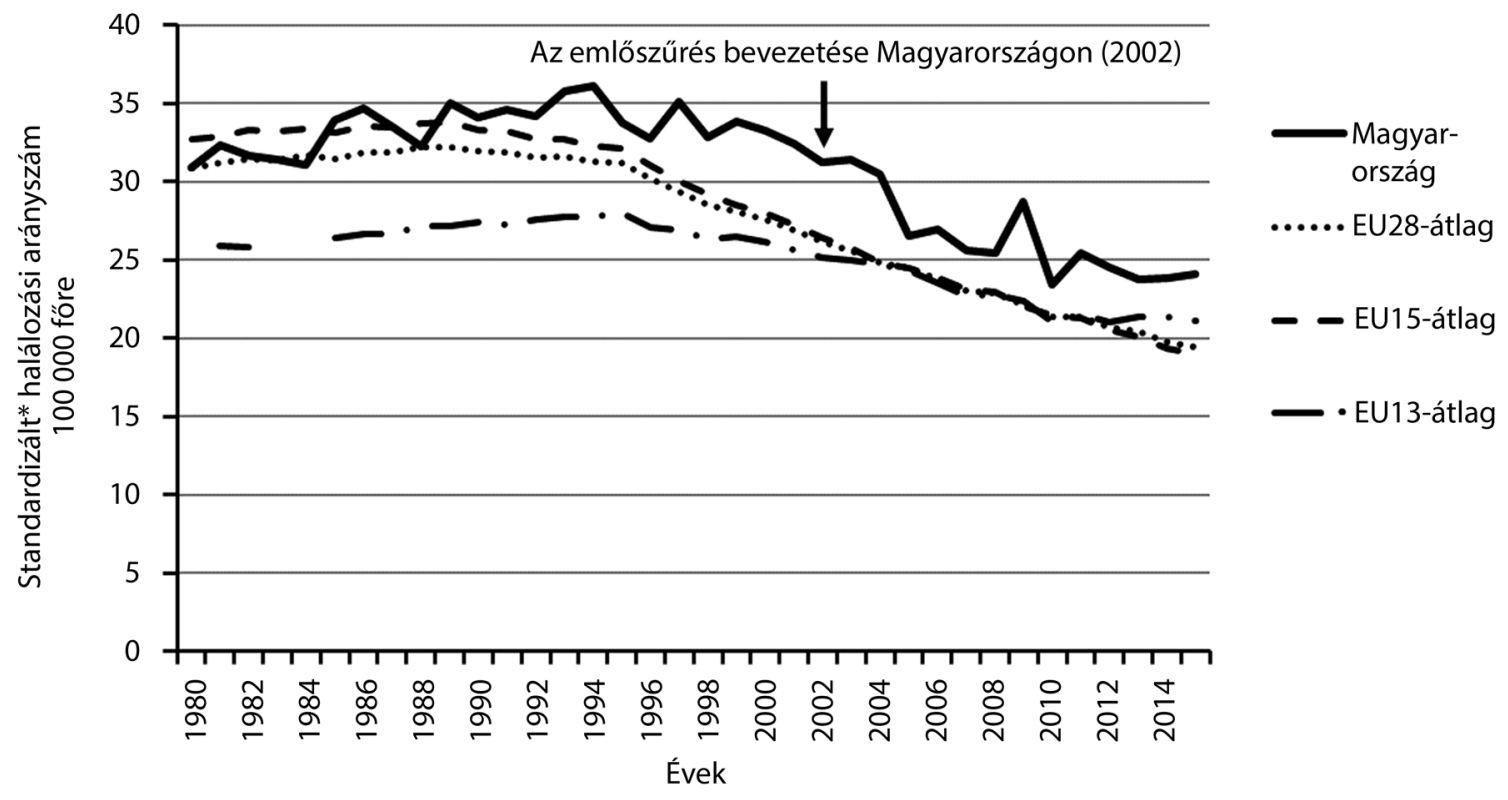

1. ábra $\quad$ A 25-64 éves nók emlőrák miatti halálozásának alakulása Magyarországon és az EU-országok átlagában, 1980-2015

*Standard: Az európai standard populáció kormegoszlása

Forrás: WHO European Health Information Gateway, 2018

$\mathrm{EU}=$ Európai Unió 


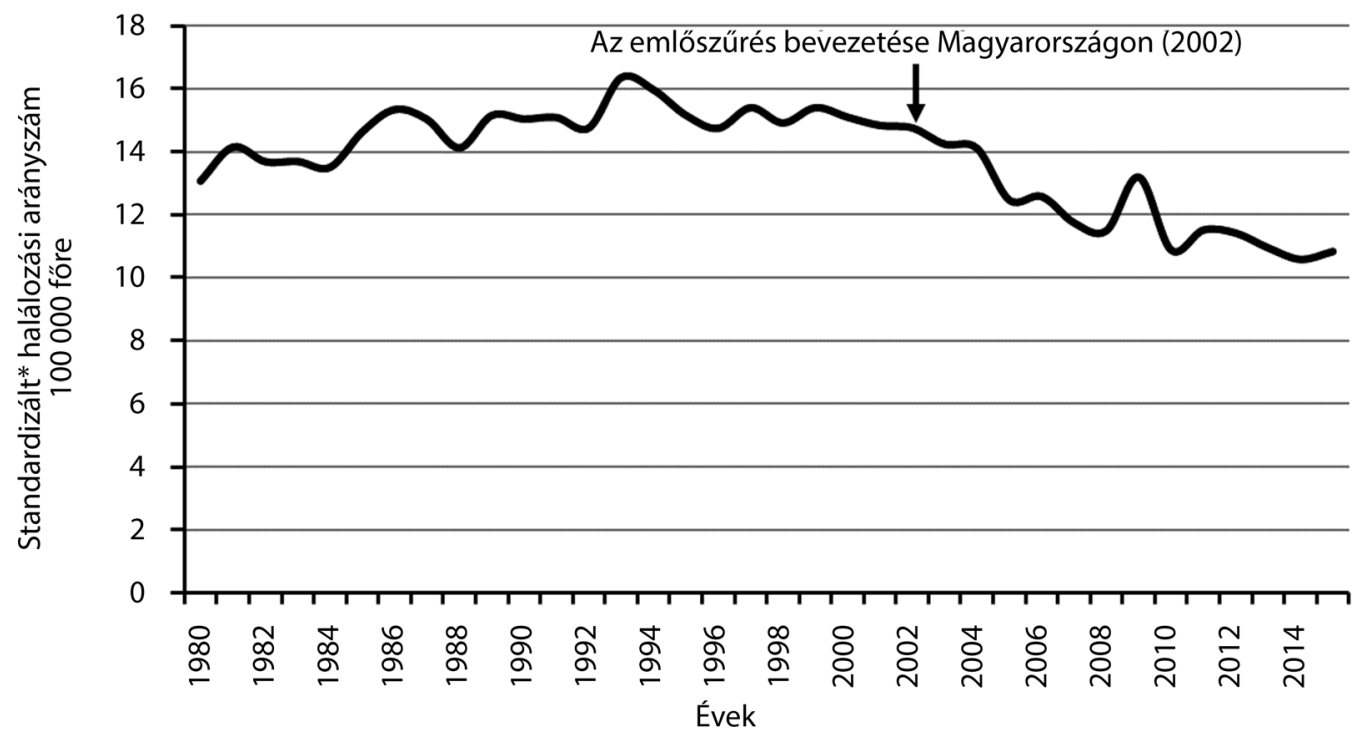

2. ábra

A 45-64 éves nők emlőrák miatti halálozásának alakulása Magyarországon, 1980-2015

*Standard: Az európai standard populáció kormegoszlása

Forrás: WHO European Health Information Gateway, 2018

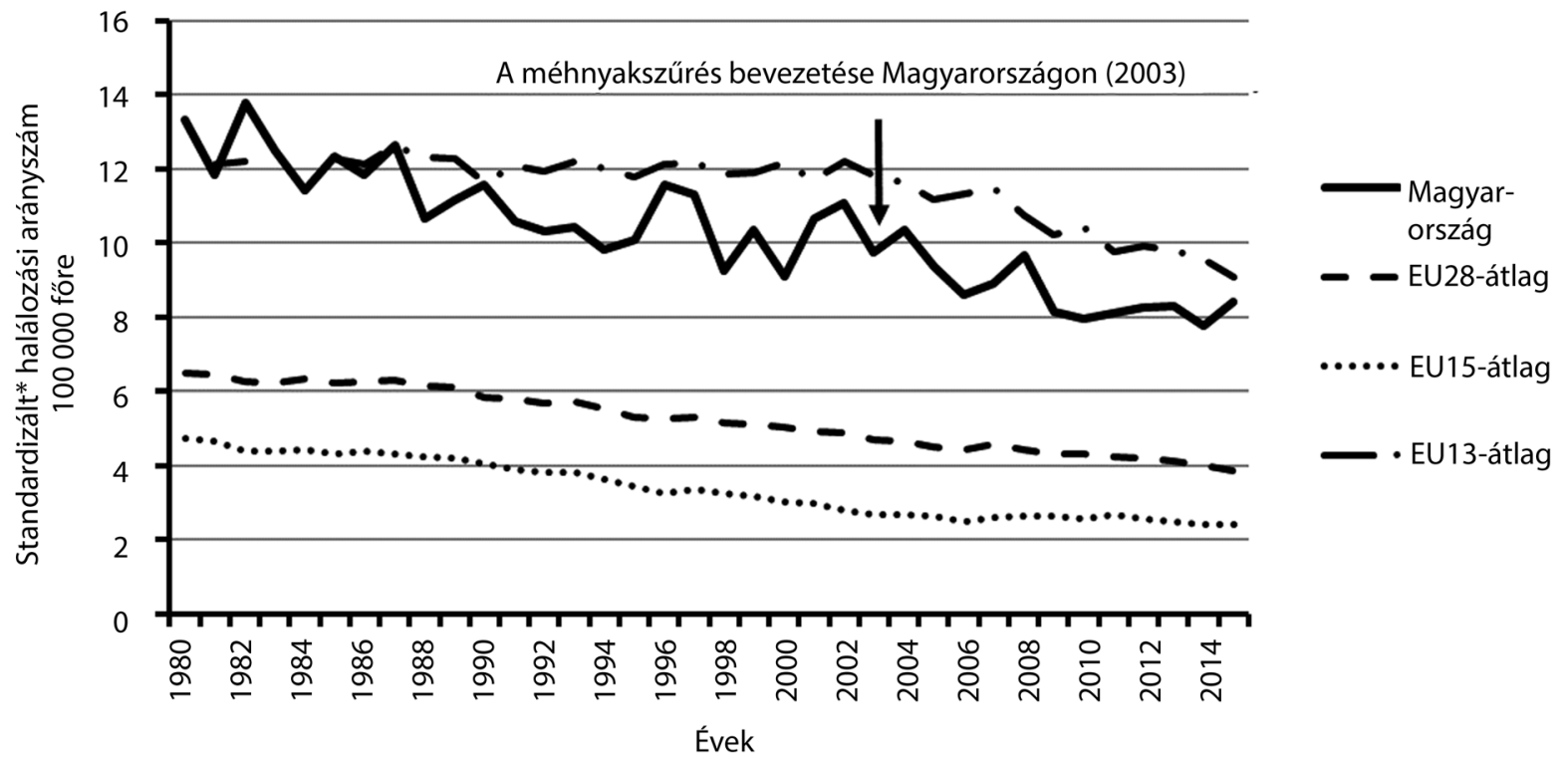

3. ábra

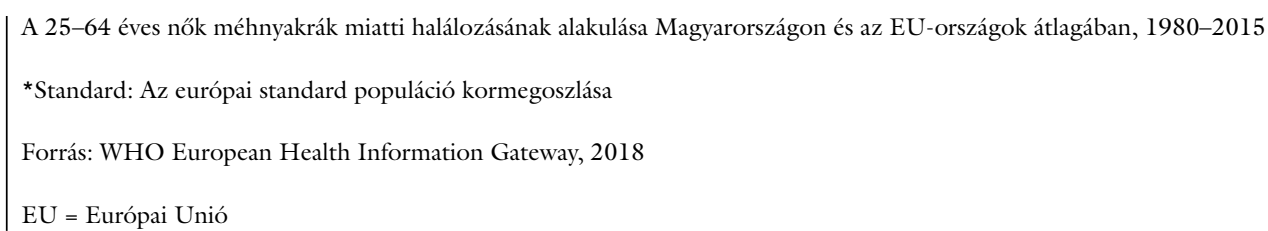

64 éves női korcsoportban a legnagyobb mértékű javulás az emlőrák okozta halálozásban Magyarországon és az EU15-országokban következett be (több, mint 21\%), de az EU28-országokban is ötödével csökkent a halálozás szintje. Az EU13-országokban átlagban csupán 16,5\%kal csökkent a halálozás.

Külön vizsgáltuk a emlőszűréssel érintett 45-64 éves női korcsoport halálozásának alakulását Magyarországon 1980 és 2015 között (2. ábra). A 45-64 éves nők emlő- rák okozta halálozása 1980-tól 1993-ig emelkedett, 1994-től csökkenő tendenciát mutatott. Az emlőszűrési program bevezetése után a magyar nők emlőrák okozta halálozásában jelentős mértékú csökkenés következett be, 2002 és 2012 között 28,3\%-kal csökkent a halálozásuk.

A magyar nók méhnyakrák miatti korai halálozása a vizsgált időszakban folyamatos csökkenést mutatott egészen 2009-ig, azóta stagnál a halálozásuk (3. ábra). 
2. táblázat | A 25-64 éves nők méhnyakrák miatti halálozásának csökkenése Magyarországon és az EU-országcsoportokban, 2002-2012

\begin{tabular}{lccc}
\hline Magyarország & EU28-átlag & EU15-átlag & EU13-átlag \\
$25,5 \%$ & $14,8 \%$ & $7,2 \%$ & $21,0 \%$ \\
\hline
\end{tabular}

Forrás: WHO European Health Information Gateway, 2018

$\mathrm{EU}=$ Európai Unió

Az EU-országcsoportokban folyamatos volt a csökkenés az egész időszak alatt. A méhnyakrák miatti korai halálozás az 1980-as évek elején a magyar nők körében az EU13-országok átlagával egyezett meg, és jelentősen magasabb volt az EU15-országok halálozásához képest. A vizsgált időszak végére a magyar nők halálozása kedvezóbb lett, mint az EU13-országok átlaga, az EU15-országok átlagához képest 2015-ben még mindig 3,5-szeres volt a különbség.

Vizsgáltuk a méhnyakrák okozta halálozás változását Magyarországon és az EU-országcsoportokban a 20022012-es időszakban (2. táblázat). A méhnyakszüréssel érintett 25-64 éves korcsoportban a méhnyakrák okozta halálozás Magyarországon több mint negyedével, az EU13-országokban több mint ötödével, míg az EU28országokban közel 15\%-kal csökkent. A legkisebb mértékü csökkenést az EU15-országokban regisztrálták.

\section{Az emlö- és méhnyakrák okozta megbetegedés alakulása}

Magyarországon évente 7-8000 emlörákos megbetegedést és 450-550 in situ carcinomát regisztrálnak, amelyből a 45-64 éves korosztályra 3-3500 megbetegedés és
2-300 in situ carcinoma jut. A 45-64 éves magyar nők emlőrák-megbetegedése jelentősen magasabb, mint a halálozás szintje, ami azt jelzi, hogy a Nemzeti Rákregiszter megfelelő hatékonysággal múködik (4. ábra). Az emlőrák incidenciája a szúrés bevezetésének évében, 2002-ben növekedett meg jelentősen, majd 2007-ig csökkenő, utána stagnáló értékeket mutatott. Az illesztett lineáris trendvonalat egyértelmúen csökkenés jellemezte $\left(\mathrm{R}^{2}=0,38\right)$. Ha az első év (2001) adatát kivesszük az elemzésből, a trendvonal illeszkedése sokkal erősebb $\left(\mathrm{R}^{2}=0,62\right)$. Ezzel szemben az emlő in situ carcinomája 2001-től 2006-ig folyamatos növekvő, majd néhány év stagnálás után újra növekvő tendenciát mutatott 2013ig. Az illesztett lineáris trendvonal egyértelmúen növekvő tendenciát mutatott $\left(\mathrm{R}^{2}=0,74\right)$. Ezzel az emlő in situ carcinoma gyakorisága 2005 óta szinte minden évben magasabb, mint a halálozás szintje. A halálozás trendje kismértékben csökkenő volt $\left(\mathrm{R}^{2}=0,79\right)$. Az emlőrák incidenciája jelentősen, több, mint 10-szer magasabb az emlö in situ carcinoma gyakoriságához képest. Az emlőrák incidenciája 2002 és 2012 között összességében 23,6\%-kal csökkent, míg az emlő in situ carcinomája 5,43/100 000-ről 18,56/100 000-re, azaz 242\%-kal növekedett.

Vizsgáltuk az emlőrák incidenciájának alakulását a 25-X éves női korosztályban 5 éves korcsoportos bontásban, hogy megállapítsuk, mely korcsoportokban, milyen gyakorisággal diagnosztizálják a betegséget (5. ábra). Az emlőrák incidenciája nagyon alacsony a 25-39 éves korosztályban, majd jelentősen emelkedik a 45-59 évesek körében; az emelkedés a 60-64 éves korosztályig tart, onnantól kezdve stagnálás tapasztalható. A 60-64 éves korosztályban az incidencia közel kétszerese a 45-59 éves korosztályénak.

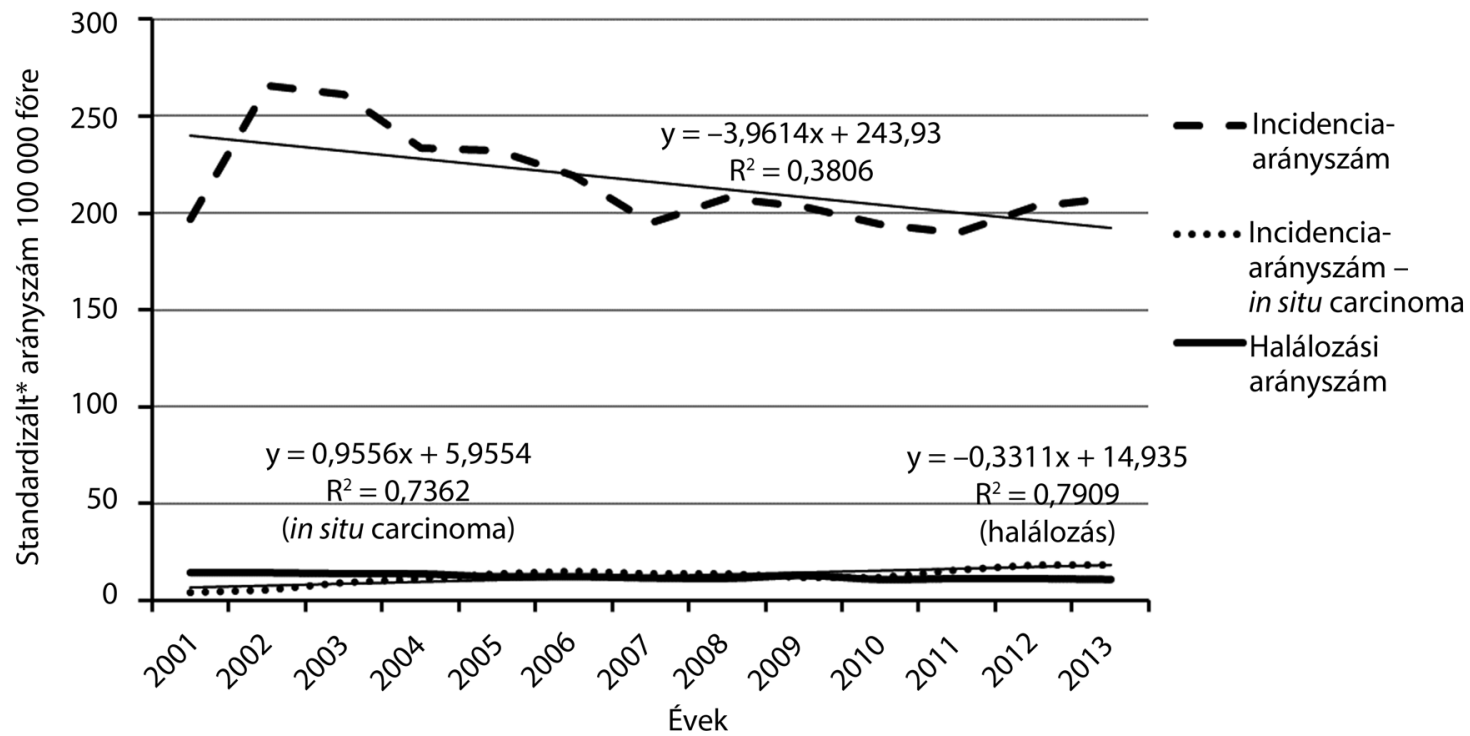
A 45-64 éves nők emlőrák-, emlőrák in situ carcinoma incidenciájának, valamint emlőrák miatti halálozásának alakulása Magyarországon, 2001-2013
*Standard: Az európai standard populáció kormegoszlása
Forrás: WHO European Health Information Gateway, 2018; Nemzeti Rákregiszter, 2018 


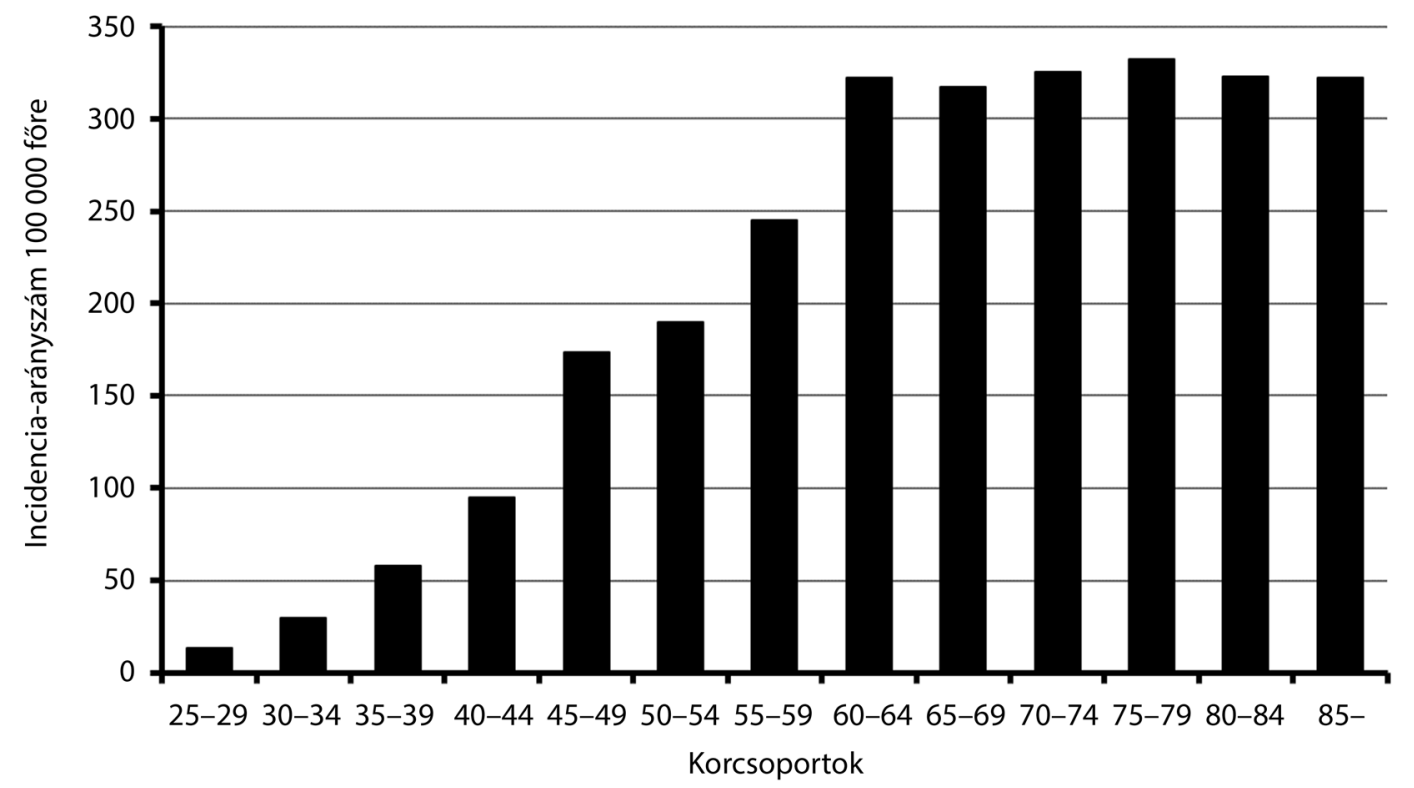

5. ábra

Az emlőrák incidenciája a 25-X éves nők körében korcsoportok szerint Magyarországon (2011-2013, átlag)
Forrás: Nemzeti Rákregiszter, 2018

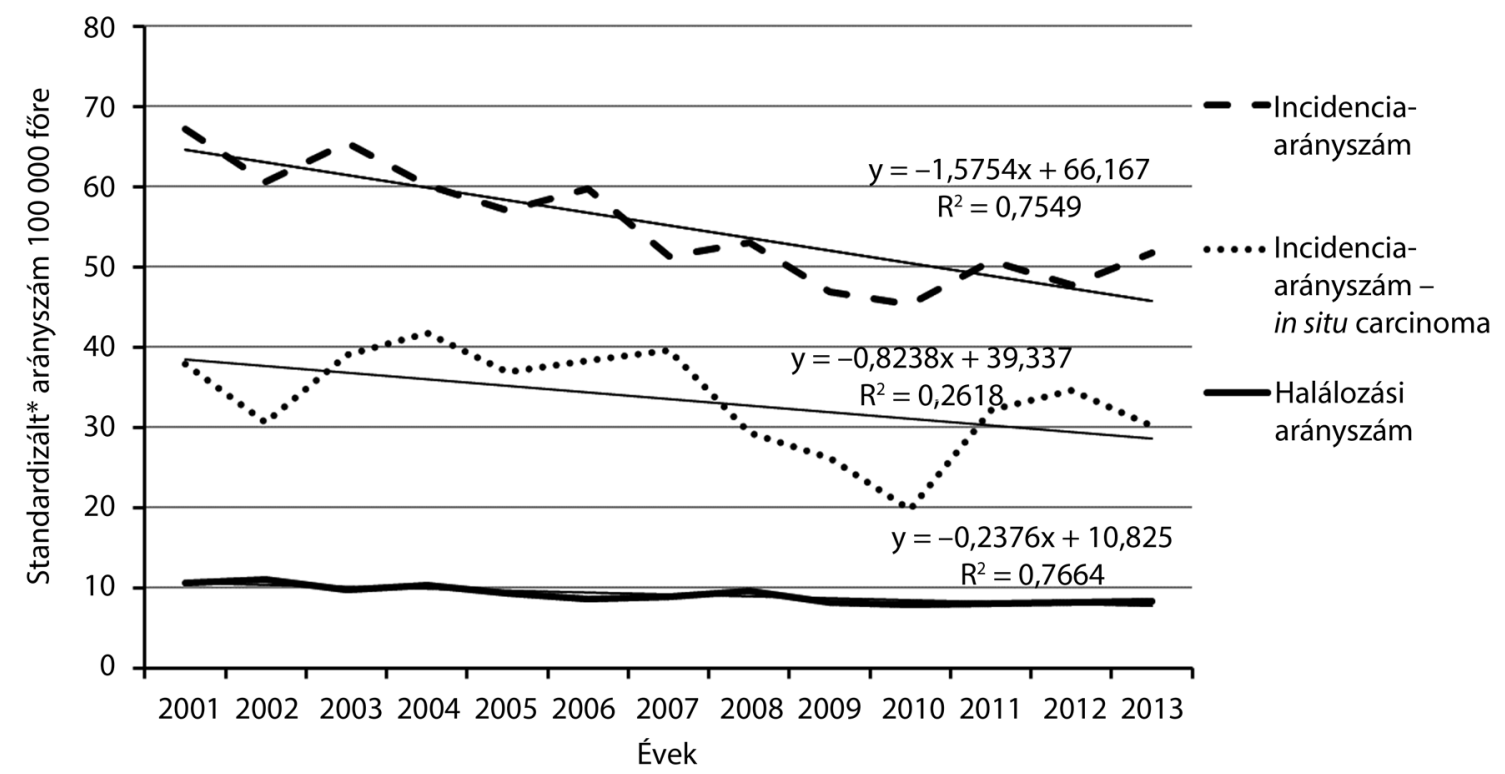

6. ábra

A 25-64 éves nők méhnyakrák-, méhnyakrák in situ carcinoma incidenciájának, valamint méhnyakrák miatti halálozásának alakulása Magyarországon, 2001-2013

*Standard: Az európai standard populáció kormegoszlása

Forrás: WHO European Health Information Gateway, 2018; Nemzeti Rákregiszter, 2018

Magyarországon évente kb. 1000-1100 méhnyakrákot és 4-600 in situ carcinomát diagnosztizálnak. Az esetek 75-80\%-a a 25-64 éves korosztályban (700-800 méhnyakrák és 450-500 in situ carcinoma) következik be. A méhnyakrák incidenciája - az emlőrákhoz hasonlóan - számottevően magasabb, mint a méhnyakrák okozta halálozás (6. ábra). A méhnyakrák incidenciája a vizs- gált időszakban alapvetően csökkenő tendenciát mutatott (erôsen csökkenő a lineáris trendvonal $\left[\mathrm{R}^{2}=0,75\right]$ ), míg az in situ carcinoma incidenciája viszonylag magas volatilitás mellett az időszak elején stagnált, majd 2007 és 2010 között egy nagyobb csökkenést követően 2 év alatt jelentős emelkedést mutatott, összességében azonban csökkenő trend jellemezte, a lineáris trendvonal illeszke- 


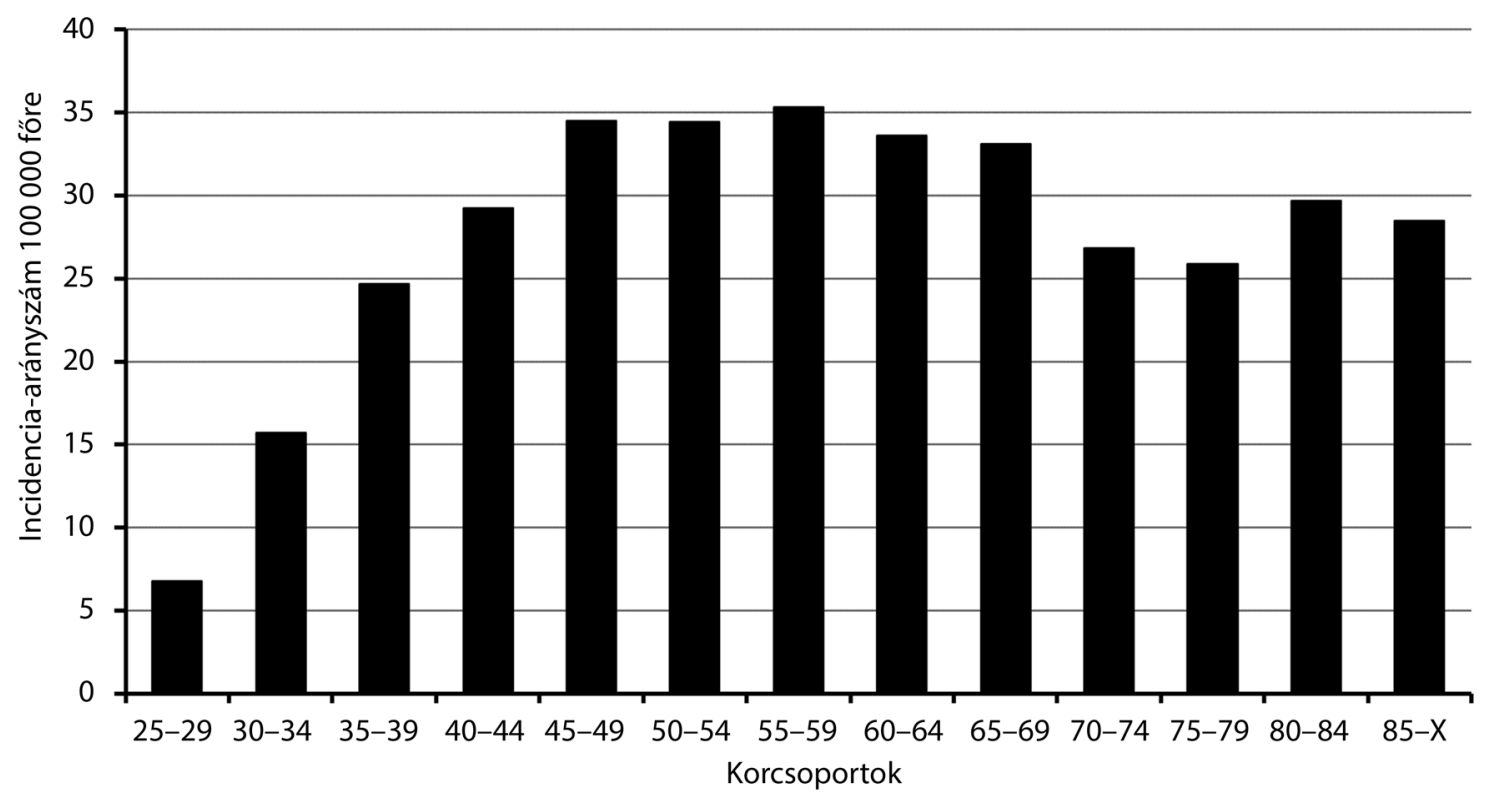

7. ábra A méhnyakrák incidenciája a 25-X éves nők körében korcsoportok szerint Magyarországon (2011-2013, átlag)
Forrás: Nemzeti Rákregiszter, 2018

dése gyenge volt $\left(\mathrm{R}^{2}=0,26\right)$. A méhnyakrák miatti halálozást kismértékű csökkenő trend jellemezte $\left(\mathrm{R}^{2}=0,77\right)$. A méhnyakrák incidenciája 2002 és 2012 között 21,2\%kal mérséklődött, míg az in situ carcinoma incidenciája 13,3\%-kal növekedett. Ez utóbbi esetén a nagy évenkénti volatilitás miatt nem beszélhetünk tendenciózus növekedésről, sőt a trendvonal csökkenő tendenciát mutat.

Vizsgáltuk a méhnyakrák incidenciáját 5 éves korcsoportos bontásban (7. ábra). A ményakrák gyakorisága a szexuális élet megkezdését követően a 25-29 éves korcsoporttól kezdve meredeken emelkedik, a maximumát a 45-69 éves korcsoportban éri el. A 45-59 éves korosztályban 5-ször magasabb az incidencia, mint a 25-29 éves korosztályban. A 70-X éves korcsoportokban bár csökken az incidencia, a szintje továbbra is magas.

\section{Megbeszélés és következtetések}

Az emlő- és a méhnyakrák továbbra is jelentős súllyal járul hozzá a nók rosszindulatú daganatos halálozásához mind a világon, mind Magyarországon [2, 3, 27]. A rosszindulatú daganatos betegségek okozta halálozás növekedésének megállítása, illetve mérséklése érdekében - a nemzetközi ajánlások figyelembevételével - került bevezetésre Magyarországon a népegészségügyi program keretében a szervezett emlö- és méhnyakszürési program [11, 12]. Ezzel párhuzamosan indult el a Nemzeti Rákregiszter is, amelybe a szolgáltatók 2000-től jelentik a diagnosztizált rosszindulatú daganatokat [26]. Vizsgálatunk célja a rendelkezésre álló emlő- és méhnyakrák-halálozási és -megbetegedési adatok elemzése, a népegészségügyi programban az emlő- és méhnyakszűrő programokkal kapcsolatban megfogalmazott célok teljesülésének értékelése.

A szűrővizsgálatok bevezetését követően hosszú távon mind a halálozás, mind a megbetegedés - elsősorban az előrehaladott stádiumú daganatok incidenciájának mérséklődése várható $[4,23,24]$. Magyarországon az emlőrák miatti halálozás a szürésbe bevont 45-64 éves korcsoportban 2002 és 2012 között 28,3\%-kal csökkent, ami megközelíti a népegészségügyi programban kitűzött 30\%-os arányt, tehát a kitűzött cél teljesült. Ugyanakkor az eredményértékelés kapcsán figyelembe kell venni, hogy a 25-64 éves korcsoportban az EU15-országokban 1980-tól a 1990-es évek elejéig növekedett a halálozás, és csak ezután következett be egy hasonló mértékü, 20\%-os csökkenés, pedig ezekben az országokban már jóval hamarabb bevezették a szűrést. Az EU13-országokban, melyek közül 2016-ban csak Észtország, Lettország, Horvátország és Magyarország rendelkezett populációs szintű emlőszűrési programmal, szintén 16,5\%-kal csökkent a halálozás 2002 és 2012 között [28]. Tehát a mortalitáscsökkenéshez az emlőrák hatékonyabb kezelése feltételezhetően nagyobb mértékben járult hozzá, mint a szürés bevezetése. Ezt erősítik meg azok a legutóbbi tanulmányok is, amelyek szerint az emlőszűrés mortalitáscsökkentő hatását vizsgáló korábbi tanulmányok kivitelezése és/vagy statisztikai analízise hibás volt, ami a mortalitáscsökkentő hatás túlbecsléséhez vezetett $[22,23]$. Továbbá az emlőszürésre meghívott nők körében legalább 20\%-os túldiagnosztizálással kell számolni az összes emlőrák tekintetében és 30-50\%os túldiagnosztizálással a szúréssel felfedezett emlőrákok esetén, ami jelentős fizikai, pszichés és gazdasági teherrel jár $[22,23]$. Az emlőrák incidenciája a szürés bevezeté- 
sének évében növekedett, majd csökkenő tendenciát mutatott a következő 5 évben. Az emlö in situ carcinoma gyakorisága jelentősen, több, mint a 3-szorosára növekedett, ami pozitív, hiszen a szűréstől a korai stádiumú daganatok felfedezését várjuk, ugyanakkor ennek egy része túldiagnosztizált daganat lehetett. Az emlőrák gyakorisága a 45 éves korcsoportban növekszik meg számottevően az életkor elörehaladtával, a 60-64 éves korcsoportig nő a gyakorisága, ami a szûréssel lefedett korcsoportot jelenti.

A méhnyakrák okozta halálozás a 25-64 éves célcsoportban a 2002-2012-es időszakban több mint egynegyedével csökkent Magyarországon, ami jelentősen elmarad a 60\%-os célkitüzéstől. Az EU15-országokban bekövetkezett kisebb, mint 10\%-os csökkenés ugyanebben az időszakban annak tulajdonítható, hogy ezekben az országokban már 2002-ben is nagyon alacsony volt a méhnyakrák miatti halálozás szintje. Az EU13-országokban annak ellenére következett be egy több, mint 20\%-os csökkenés, hogy a teljes lakosságra kiterjedő méhnyakszürési programmal csak Észtország, Lettország, Lengyelország, Szlovénia és Magyarország rendelkezett [28]. Ezek alapján megállapíthatjuk, hogy a magyarországi halálozáscsökkenés elsősorban a kezelésben és a rizikófaktorok csökkenésében bekövetkezett változásoknak köszönhető, a szưrés nem múködik hatékonyan annak ellenére, hogy a szưréshez való hozzáférés javítása érdekében először 2009-ben 'pilot' jelleggel, majd 2013 és 2015 között országos kiterjesztéssel elindult a védőnői méhnyakszűrési program [29]. Ezt erősíti meg az az adat is, hogy 2015-ben Magyarországon 3,5-szer volt magasabb a 25-64 éves nők halálozása az EU15-országok átlagához képest. A méhnyakrák incidenciája 2002 és 2012 között egynegyedével csökkent - ami a rizikófaktorok csökkenését mutatja -, az in situ carcinoma gyakorisága viszont magas volatilitás mellett kismértékben emelkedett, a tendencia azonban ebben az esetben is csökkenő volt. A méhnyakrák gyakorisága a kor előrehaladtával, 25 éves kortól 45 éves korig gyorsan növekszik, ami indokolja a szűrés fenntartását a 25-64 éves korcsoportban. Ugyanakkor a szűrés jelenlegi rendszerének és az alkalmazott szűrőmódszernek az áttekintése javasolt, figyelembe véve, hogy Magyarországon 2014-ben elindult a hetedik osztályos lányok önkéntes HPV-oltása, továbbá több ország, így Dánia, Írország és Nagy-Britannia áttért a folyadékalapú citológiára, illetve például Finnország, Dánia, Franciaország, Olaszország bizonyos részein a HPV-szűrést ajánlják fel egyedüli szűrésként a citológiai szürés helyett [28].

A bevezetett szűrések hatékonyságának korrekt értékeléséhez az elörehaladott stádiumú daganatok incidenciájában bekövetkezett változás elemzésére lenne szükség, azonban a Nemzeti Rákregiszterben egyelőre csak az összincidencia és az in situ carcinoma incidencia (abszolút számok formájában) adatai állnak rendelkezésre. Ezért szükséges lenne a Nemzeti Rákregiszterben gyưjtött adatok bővítése - ami viszonylag egyszerüen megva- lósítható a fekvőbeteg-ellátó intézményekben keletkezett adatok elektronikus továbbításával -, illetve a gyưjiött adatok folyamatos és többszintü feldolgozása, ami segítheti az egészségpolitikai döntéshozatalt.

Anyagi támogatás: A kutatás és a kézirat elkészítése anyagi támogatásban nem részesült.

Szerzői munkamegosztás: S. A.: A kutatás tervezése, koordinálása, az adatok elemzése, a kézirat elkészítése. B. P. Cs.: Az adatok elemzése, az ábrák elkészítése. Gy. A., K. Zs.: Részvétel a kézirat elkészítésében. A cikk végleges változatát valamennyi szerző elolvasta és jóváhagyta.

Érdekeltségek: A szerzőknek nincsenek érdekeltségeik.

\section{Köszönetnyilvánítás}

Köszönjük dr. Takács Péter főiskolai tanárnak (Debreceni Egyetem, Egészségügyi Kar, Egészségügyi Informatikai Tanszék) a statisztikai elemzés elkészítéséhez nyújtott segítségét.

\section{Irodalom}

[1] Hungarian Central Statistical Office. Demographic Yearbook 2016. [Központi Statisztikai Hivatal. Demográfiai Évkönyv 2016.] KSH, Budapest, 2017. [Hungarian]

[2] Kásler M, Ottó Sz, Kenessey I. The current situation of cancer morbidity and mortality in the light of the National Cancer Registry. [A rákmorbiditás és -mortalitás jelenlegi helyzete a Nemzeti Rákregiszter tükrében.] Orv Hetil. 2017; 158: 84-89. [Hungarian]

[3] Sárváry A. Premature cancer mortality of Hungarian women between 1980 and 2011. [A magyar nők rosszindulatú daganatos betegségek miatti korai halálozásának jellemzői 1980 és 2011 között.] Acta Med Soc. 2015; 6: 59-78. [Hungarian]

[4] The Council of the European Union. Council recommendation of 2 December 2003 on cancer screening $(2003 / 878 / E C)$. Official Journal of the European Union, 16.12.2003. Available from: http://eur-lex.europa.eu/LexUriServ/LexUriServ.do?uri =OJ:L:2003:327:0034:0038:EN:PDF [accessed: September 22, 2018].

[5] Anttila A, Ronco G, Clifford G, et al. Cervical cancer screening programmes and policies in 18 European countries. Br J Cancer 2004; 91: 935-941.

[6] Simon J. The situation of epidemiology, prevention and screening in the field of gynecologic oncology. [Az epidemiológia, megelőzés és szűrés helyzete a nőgyógyászati onkológia területén.] Magy Nőorv L. 1994; 57(2 Suppl): S75-S80. [Hungarian]

[7] Bodó M, Döbróssy L. Results and future of cervixprogramme based on citology. [A citológiai vizsgálatra alapozott cervixprogram eredményei és kilátásai.] Orvostudomány 1982; 33: 391395. [Hungarian]

[8] Bodó M, Döbrőssy L, Liszka G, et al. Cancer screening in Hungary: World Bank supported model programs. [Rákszűrés Magyarországon: Modellprogramok világbanki támogatással.] Orv Hetil. 1997; 138: 1801-1804. [Hungarian]

[9] Döbrőssy L. Five decades of cervical screening in Hungary. [Méhnyakrákszűrés öt évtizede Magyarországon.] Nőgyógy Onkol. 2007; 12: 5-9. [Hungarian]

[10] Lengyel L, Fábián E, Kozlovszky B, et al. Breast cancer screening, early diagnosis of breast cancer. [Emlőszürés, az emlőrák 
korai diagnózisa.] Orvosképzés 1987; 62: 405-411. [Hungarian]

[11] Healthy Nation Public Health Programme 2001-2010. [Egészséges Nemzetért Népegészségügyi Program 2001-2010.] Eü Közl. 2001; 16. szám, 2001. aug. 21. [Hungarian]

[12] 46/2003 (IV. 16.) Parliamentary resolution about Johan Béla National Programme for the Decade of Health. [46/2003 (IV. 16.) OGY-határozat az Egészség Évtizedének Johan Béla Nemzeti Programjáról.] Available from: https://mkogy.jogtar. hu/jogszabaly?docid=a03h0046.OGY [accessed: June 12, 2018]. [Hungarian]

[13] Péntek Z. National and international experiences of mammography screning. [A mammográfiás emlőszưrés nemzetközi és hazai tapasztalatai.] LAM 2002; 12: 232-234. [Hungarian]

[14] Országos Tisztiföorvosi Hivatal Méhnyakszúrési Munkacsoport. Population based cervical screening in the frame of "Decade of Health": directions for improving the gynecological cancer screening in Hungary. [Lakossági méhnyakszürés az „Egészség Évtizede” program keretében: törekvések a nőgyógyászati rákszűrés korszerüsítésére Magyarországon.] Orv Hetil. 2004; 145: 35-40. [Hungarian]

[15] Boncz I, Sebestyén A, Döbrőssy L, et al. The attendance of the first screening round (2002-2003) of the Hungarian organized breast cancer screening programme and its effect on the number of the diagnostic and screening mammography. [A szervezett emlőszűrési program 2002-2003. évi részvételi arányai és a program hatása a diagnosztikus és szúrési célú mammográfiák számára.] Orv Hetil. 2005; 146: 1963-1970. [Hungarian]

[16] Boncz I, Sebestyén A, Döbrőssy L, et al. The attendance of the second screening period (2004-2005) of the Hungarian organized breast cancer screening program. [A szervezett emlőszúrési program második ciklusának (2004-2005) részvételi arányai.] Orv Hetil. 2008; 149: 1491-1498. [Hungarian]

[17] Boncz I, Döbrössy L, Péntek Z, et al. The attendance of the third (2006-2007) screening round of the Hungarian organised breast cancer screening programme. [A szervezett emlőszűrési program harmadik (2006-2007) szúrési ciklusának részvételi arányai.] Magy Onkol. 2013; 57: 140-146. [Hungarian]

[18] Boncz I, Döbrőssy L, Péntek Z, et al. Attendance of the fourth (2008-2009) screening round of the Hungarian organized, nationwide breast cancer screening program. [A szervezett országos emlőszưrési program negyedik (2008-2009) szűrési körének részvételi arányai.] Orv Hetil. 2013; 154: 1975-1983. [Hungarian]

[19] Boncz I, Sebestyén A, Döbrőssy L, et al. The coverage of cervical screening in Hungary. [A méhnyakszűrés részvételi mutatói
Magyarországon.] Orv Hetil. 2007; 148: 2177-2182. [Hungarian]

[20] Shapiro S, Venet W, Strax P, et al. Ten- to fourteen-year effect of screening on breast cancer mortality. J Natl Cancer Inst. 1982; 69: 349-355.

[21] Frisell J, Lidbrink E, Hellström L, et al. Followup after 11 years - update of mortality results in the Stockholm mammographic screening trial. Breast Cancer Res Treat. 1997; 45: 263-270.

[22] Gøtzsche PC, Jørgensen KJ. Screening for breast cancer with mammography. Cochrane Database Syst Rev. 2013; 6: CD001877. Available from: https://www.cochranelibrary. com/cdsr/doi/10.1002/14651858.CD001877.pub5/media/ CDSR/CD001877/CD001877_standard.pdf [accessed: June $10,2018]$.

[23] Autier P, Boniol M. Mammography screening: a major issue in medicine. Eur J Cancer 2018; 90: 34-62.

[24] Lăără E, Day NE, Hakama M. Trends in mortality from cervical cancer in the Nordic countries: association with organised screening programmes. Lancet 1987; 1(8544): 1247-1249.

[25] WHO, Regional Office for Europe. European Health Information Gateway, 2018. World Health Organization, Geneva. Available from: https://gateway.euro.who.int/en/hfa-explorer/ [accessed: June 22, 2018].

[26] National Cancer Registry. [Nemzeti Rákregiszter.] Available from: http://www.onkol.hu/hu/nemzeti_rakregiszter [accessed: May 12, 2018]. [Hungarian]

[27] Winters S, Martin C, Murphy D, et al. Breast cancer epidemiology, prevention, and screening. Prog Mol Biol Transl Sci. 2017; 151: 1-32.

[28] Basu P, Ponti A, Anttila A, et al. Status of implementation and organization of cancer screening in The European Union Member States - Summary results from the second European screening report. Int J Cancer 2018; 142: 44-56.

[29] Gyulai A, Fehér E, Balázs I. Role of health visitors in the prevention of cervical cancer. Experiences of Health Visitor Cervical Screening Programme in Hungary. [A védőnők szerepe a méhnyakrák megelőzésében. A Védőnői Méhnyakszúrő Programok tapasztalatai Magyarországon.] Acta Med Soc. 2015; 6: 21-38. [Hungarian]

\title{
Az Orvosi Hetilap 2019, 160, 1764. oldalán (44. szám) megjelent OH-Kvízre három helyes megfejtés érkezett.
}

\author{
A beküldők: Dr. Bíró László (Budapest), Dr. Janik Leonárd (Budapest) \\ és Dr. Somogyi Erzsébet (Miskolc).
}

A nyerteseknek szívböl gratulálunk.

\author{
A nyereményüket - egy, az Akadémiai Kiadó webáruházában \\ kedvezményes vásárlásra jogosító kupont - e-mailen küldjük el.
}

A cikk a Creative Commons Attribution 4.0 International License (https://creativecommons.org/licenses/by/4.0/) feltételei szerint publikált Open Access közlemény, melynek szellemében a cikk bármilyen médiumban szabadon felhasználható, megosztható és újraközölhetö, feltéve, hogy az eredeti szerző és a közlés helye, illetve a CC License linkje és az esetlegesen végrehajtott módositások feltüntetésre kerülnek. (SID_1) 